\title{
THE EFFECT OF DISCOVERY LEARNING AND LEARNING MOTIVATION ON STUDENT LEARNING OUTCOMES PPKN SUBJECTS IN CLASS IV SDN 105316 BERANTI
}

\author{
Polintan Rehulina Sembiring ${ }^{1}$ \\ State University of Medan, Indonesia \\ E-mail : polintanrehulinasem@gmail.com
}

Reh Bungana Br. Perangin-Angin ${ }^{2}$

State University of Medan, Indonesia

Yakobus Ndona ${ }^{3}$

State University of Medan, Indonesia

\begin{abstract}
This study aims to determine: 1) The effect of discovery learning and conventional learning models on student learning outcomes, 2) The influence of learning motivation on student learning outcomes. 3) The interaction between learning models and learning motivation on student learning outcomes. This study used a quasi-experimental research method. The research was conducted from April to May 2021.The population of this study were the fourth grade students of SDN 105316 Beranti, the number of which was 42 students who were determined randomly by random sampling technique. The research sample was 22 students of class IVA as the experimental class and 22 students of IVB class as the control class. The data collection technique used a learning motivation questionnaire and a learning outcome test. The data analysis technique used two-way analysis of variance. The results of the study are as follows: (1) There are differences in learning outcomes students who are taught with a learning model discovery learning with an average value of 85,919 higher than the learning outcomes of students taught by the learning model conventional on average 80,000 , the analysis of variance results show $F_{\text {count }}$ value of $4.333>F_{\text {table }}$ value of 3.22 and a probability or significance value of $0.00<0.05$, so $\mathrm{HO}$ is rejected, (2) There is a significant difference between student learning outcomes with high learning motivation and the average85.07and students who have low
\end{abstract}


learning motivation on average 57.81. Result of analysis of variance obtained $F_{\text {count }}$ value of $79.45>F_{\text {table }}$ value of 3.22 and a significant value of $0.013<0.05$, so that $\mathrm{H}_{0}$ is rejected., (3) There is an interaction between discovery learning model and student motivation in improving student PPKn learning outcomes, analysis of variance results $F_{\text {count }}$ value of $8.807>F_{\text {table }}$ value of 3.22 and a significance of $0.014<0.05$, so that $H_{0}$ is rejected.

Keywords: Learning Models, Learning Motivation, Learning Outcomes of PPKn

\section{A. Introduction}

Learning motivation is the basic impulse that moves a person to behave. Sardiman (2018: 75) states that learning motivation is the overall driving force in students that gives rise to learning activities that ensure the continuity of learning activities and provide direction to learning activities, so that the goals desired by the learning subject can be achieved.

External factors, namely from outside the students, the teacher is not creative in using learning media and the learning model used by the teacher is still monotonous and rigid. This causes the teaching and learning process in the classroom to be unattractive and boring for students, so that it has an impact on student learning outcomes that have not been maximized, especially Civics.

The problem also occurs in SDN 105316 Beranti. Based on the results of the interview with the fourth grade homeroom teacher, Mrs. Njorekenca Br Ginting, S.Pd Monday, January 10, 2021, in the learning process, teachers tend to still use conventional learning models in class such as question and answer, memorization, and assignments so that students are passive, not creative and have good motivation. low in learning. This is evidenced by the scores of students final semester exam 
results which show that there are student scores below the Minimum Completeness Criteria (KKM) of 75.

A good learning model for students, if it can create effective, fun and meaningful learning. Interesting learning will make students enthusiastic in learning, active and focused. One of the learning models that can support the above expectations is to apply the discovery learning model. Discovery learning is a learning model that requires students to actively search for learning experiences using analysis and problem solving they face by finding and investigating themselves.

The discovery learning model has been carried out in various educational researches to increase student motivation and learning outcomes. One example of research carried out by Firosalia Kristin and Dwi Rahayu (2016) in the journal Scholaria, volume 1, number 1 with the title "The Influence of the Application of Discovery Learning Learning Models on Social Studies Learning Outcomes in Grade 4 Elementary School Students", concluded that the use of discovery learning learning models had an effect on on the social studies learning outcomes of 4 th grade students of SD Negeri Koripan 01, this is reinforced by information that describes the average value of social studies learning outcomes. The average value of the experimental class students is higher than the control class students scores.

The same research was also conducted by Syiti Mutia Hasnan, et al (2020) in the journal Basicedu, volume 4, number 2 with the title "The Effect of the Use of the Discovery Learning Model and Motivation on Critical Thinking Ability of Elementary School Students", concluded (1) the learning model used have an effect on students critical thinking skills with the average critical thinking ability test results given the discovery learning model treatment is 67.36 or higher than the average critical [528] 
thinking ability test results taught by conventional learning in the control class with an average of 54.13. (2) the average critical thinking ability test results of students who are taught with the discovery learning model who have a learning motivation of 17.82 are higher than those of conventional learning with a learning motivation of 15. 10. (3) there is an interaction between the learning model and motivation. This is based on the average that has been obtained.

\section{B. Method}

\section{Research Location and Time}

The research was conducted at SDN 105316 Beranti, Jalan Desa Siguci Beranti. The reasons for choosing the location were based on the following considerations (1) the school could represent the type of research with the same problem and (2) the school had problems with Civics learning outcomes that were not optimal.

The research was carried out in the even semester of April for the 2020/2021 Academic Year. Research time is adjusted to the educational calendar in the form of a teaching and learning process.

\section{Population and Research Sample}

The population of this study was all fourth grade students at SDN 105316 Beranti for the 2020/2021 academic year which consisted of 2 classes totaling 44 students, including class IV-A consisting of 22 students and class IV-B consisting of 22 students.

The sample in this study was the entire population, namely 44 students, consisting of 22 students in class VI-A and 24 students in class VI-B. The total sample size is 44 students.

\section{Treatment Controller}

Internal validity control is intended so that the results obtained are 
truly the result of the treatment given to each experimental group, so that the research results can be generalized to the research population. Controls for internal validity include: the effect of history (history effect), the effect of maturity (maturation effect), the effect of the instrument (instrient effect), the effect of subject differences (differential selection of subject effect), the effect of losing experimental participants (mortality effect), and the effect of contamination between experimental classes (selection maturation interaction effect), External Validity.

Control of internal validity is intended so that the results obtained are really the result of the treatment given to each experimental group. Internal validity controls include : Population validity and ecological validity.

\section{Data Collection Instruments and Techniques}

Based on the type of research and the problems to be studied, the data collection technique used in this research is to use a multiple choice test for learning outcomes and use a questionnaire for student motivation.

\section{Finding and Discussion}

\section{Results}

a. Pre-Test Learning Outcomes of Experimental Class Student Civics

The lowest score obtained by students is 45 and the highest score is 75 with the average obtained is 61.59 , the median is 62.50 and the mode is 65 , the standard deviation is 8.03 and the variance is 64.51 . Based on the average value, it can be said that the pre-test data on student learning outcomes still have not reached the predetermined KKM, which is 70 . 
PPKn learning outcomes of students in the experimental class with the highest number of frequencies are in the interval class 63-68, namely 6 people or $27 \%$ of students, while the lowest number of frequencies is in the $45-50$ interval class, namely 2 people or $9 \%$ students and $75-80$ namely 2 people or $9 \%$ of students.

\section{b. Pre Test of Civics Learning Outcomes for Control Class Students}

The lowest score obtained by students is 45 and the highest score is 80 with the average obtained is 60.91 , the median is 60.00 and the mode is 65 , the standard deviation is 7.63 and the largest variance is 58.26. Based on the average value, it can be said that the pre-test data on student learning outcomes still have not reached the predetermined KKM, which is 70 .

Civics learning outcomes of students in the control class with the highest number of frequencies were in the interval class 63-68, namely 6 people or $27 \%$ of students, while the least frequency was in the $75-80$ interval class, namely 1 person or $5 \%$ of students.

\section{c. Description of Experimental Class Student Learning Motivation}

It is known that from 22 students in the experimental class there are 10 people or $45 \%$ students who have high learning motivation, 12 people or $55 \%$ students who have low learning motivation. The frequency distribution of students learning motivation scores is visually shown in the following diagram: 


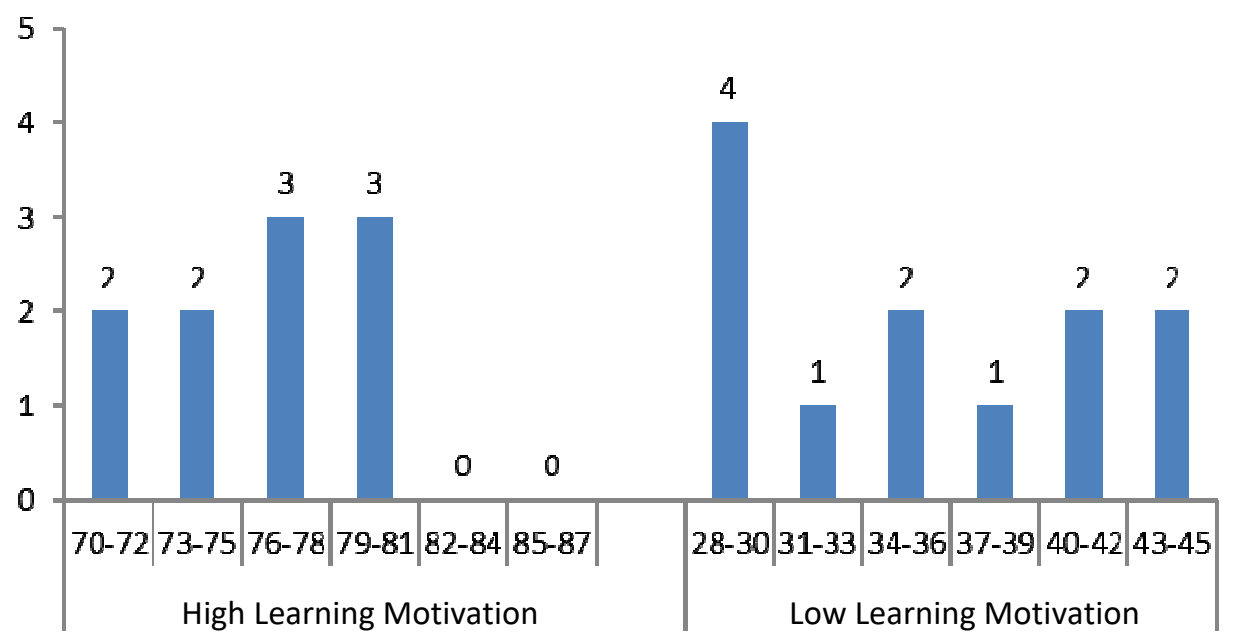

Figure 1. Experimental Class Learning Motivation Diagram

\section{d. Description of Control Class Learning Motivation}

It can be seen that from 22 students in the control class there are 8 students or $36 \%$ students who have high learning motivation and 14 students or $64 \%$ students have low learning motivation. The frequency distribution of scores has motivation to learn.

e. Post Test of Civics Learning Outcomes of Students Taught with the Discovery Learning Model

The distribution of the frequency distribution of Civics learning outcomes of students who are taught with the discovery learning model can be seen that there are $100 \%$ of students' Civics learning outcomes above the average. Based on the average value, it can be said that the Civics learning outcomes of students who are taught with the discovery learning learning model have reached the KKM that has been set, which is 70. The frequency distribution of the Civics learning outcomes scores of students who are taught with the discovery learning model.

Civics learning outcomes of students who are taught with the discovery learning learning model the highest number of frequencies are [532] 
in the $85-80$ interval class, namely 7 people or $32 \%$ of students, while the lowest frequency is in the 100-104 interval class, namely 1 person or $5 \%$ of students.

\section{f. Post Test of Civics Learning Outcomes of Students Taught with Conventional Learning Models}

The distribution of the frequency of Civics learning outcomes of students who are taught using conventional learning models can be seen that there are $95 \%$ of students' Civics learning outcomes above the average and $5 \%$ of students' learning outcomes below the average. Based on the average value, it can be said that the Civics learning outcomes of students who are taught with conventional learning models have reached the KKM that has been set, which is 70 . The frequency distribution of the Civics learning outcomes scores of students who are taught with the learning model.

Civics learning outcomes of students who are taught using conventional learning models have the highest frequency in the interval class 79-86, namely 10 students or $45 \%$ of students, while the lowest frequency is in the interval class 55-62, namely 1 person or $5 \%$ students and 95 students. -100 is 1 person or $5 \%$ of students.

\section{g. Civics Learning Outcomes of Students Who Have High Learning Motivation}

The distribution of the frequency of Civics learning outcomes for students who have high learning motivation is on average 61.79. Based on the average value, it can be said that the learning outcomes of students who have high learning motivation have reached the predetermined KKM. Distribution of the frequency distribution of the Civics learning outcomes scores of students who have high learning motivation.

Civics learning outcomes of students who have high learning 
motivation with the highest number of frequencies are in the interval class $66-68$, namely 5 people or $28 \%$ of students, while the number of frequencies with the least frequency is in the interval class 75-76, namely 1 person or $6 \%$ of students.

\section{h. Civics Learning Outcomes of Students Who Have Low Learning Motivation}

The distribution of the frequency of Civics learning outcomes of students who have low learning motivation can be seen that there are $27 \%$ of student learning outcomes above the average and $73 \%$ of student learning outcomes below the average. Based on the average value, it can be said that the learning outcomes of students who have low learning motivation have reached the predetermined KKM. Distribution of the frequency distribution of the Civics learning outcomes scores of students who have low learning motivation.

Civics learning outcomes of students who have low learning motivation with the highest number of frequencies are in the interval class 42-44, namely 5 people or 19\% of students and 45-47, namely 5 people or $19 \%$ of students, while the least number of frequencies is in the interval class $39-41$ that is 2 people or $8 \%$ of students.

\section{i. Civics Learning Outcomes of Students who are Taught with the Discovery Learning Model and Have High Learning Motivation}

The distribution of the frequency distribution of Civics learning outcomes for students who have high learning motivation is an average of 85.07. Based on the average value, it can be said that the learning outcomes of students who have high learning motivation have reached the predetermined KKM. Distribution of the frequency distribution of Civics learning outcomes scores of students who are taught by the discovery learning model and have high learning motivation. 
Civics learning outcomes of students who are taught with discovery learning learning models and have high learning motivation with the highest number of frequencies are in the 85-88 interval class, namely 4 people or $29 \%$ of students, while the least frequency is in the 93-96 interval class, namely 1 people or $7 \%$ of students.

j. Civics Learning Outcomes of Students who are Taught with the Discovery Learning Model and Have Low Learning Motivation

The distribution of the frequency of Civics learning outcomes for students who are taught using the discovery learning model and have low learning motivation has an average of 57.81. Based on the average value, it can be said that the learning outcomes of students who have low learning motivation have reached the KKM that has been set. Distribution of the frequency distribution of Civics learning outcomes scores of students who are taught by the discovery learning model and have low learning motivation.

Civics learning outcomes of students who are taught with discovery learning learning models and have low learning motivation with the highest number of frequencies are in the interval class 52-54, namely 2 people or $25 \%$ of students, 58-60, namely 2 people or $25 \%$ of students and $61-63$, namely 2 people or $25 \%$ of students while the least number of frequencies are in the 55-57 interval class, namely 1 person or $13 \%$ of students and 64-66, namely 1 person or $13 \%$ of students.

\section{k. Civics Learning Outcomes of Students who are Taught with Conventional Learning Models and Have High Learning Motivation}

The distribution of the frequency of Civics learning outcomes for students who have high learning motivation is on average 79.62. Based on the average value, it can be said that the learning outcomes of students who have high learning motivation have reached the KKM that has been 
set. Distribution of the frequency distribution of Civics learning outcomes scores of students who are taught using conventional learning models and have high learning motivation

Civics learning outcomes of students who are taught using conventional learning models and have high learning motivation with the highest number of frequencies are in the interval class 77-83, namely 4 people or $31 \%$ students and $84-90$, namely 4 people or $31 \%$ students, while the highest frequency few are in the class interval 91-97, namely 1 person or $8 \%$ of students.

\section{Civics Learning Outcomes of Students who are Taught with} Conventional Learning Models and Have Low Learning Motivation

The frequency distribution of the results of Civics Education of students who are taught using conventional learning models and have low learning motivation can be seen that there are $89 \%$ of student learning outcomes above the average and $11 \%$ of student learning outcomes below the average. Based on the average value, it can be said that the learning outcomes of students who have low learning motivation have reached the predetermined KKM. Distribution of the frequency distribution of the Civics learning outcomes scores of students who are taught using conventional learning models and have low learning motivation.

Civics learning outcomes of students who are taught using conventional learning models and have low learning motivation with the highest number of frequencies are in class 53-56, namely 3 people or $33 \%$ of students, while the least frequency is in the interval class 41-44, namely 1 person or $11 \%$ students and $45-48$ that is 1 person or $11 \%$ students. 


\section{Discussion}

Civics Learning Outcomes of Students Taught with the Discovery Learning Model are Higher than Students Taught with the Conventional Learning Model

Based on the results of the research conducted, it was found that the average Civics learning outcomes of students taught with the discovery learning model were 81,000 . Meanwhile, the average Civics learning outcomes taught with conventional learning was 76,952. Therefore, it can be said that Civics subjects, especially in studying the struggles of the heroes, considering the average learning outcomes obtained by students are higher than the average student learning outcomes taught by conventional learning models that have been used by teachers in PPKn subjects.

Based on the results of the analysis during the research process, the researcher observed that each student had different abilities in understanding the lesson. The continuity of this research makes the researcher closer to the problem. The core of the problem found is the non-achievement of Civics learning outcomes, students need to know the struggles of heroes that can be applied in society, by applying discovery learning learning can help students easily understand concepts and know the struggles of heroes Based on this thought, it can be said that student Civics learning outcomes will be better and increase if the teacher applies the discovery learning model in helping the daily learning process.

Civics Learning Outcomes of Students with High Learning Motivation are Higher than Students with Low Learning Motivation.

Based on the results of research data analysis through the twoway ANOVA test, it was obtained that the average learning outcome of students with high learning motivation was 86,167 while the average 
learning outcomes of students who had low learning motivation was 71,786 , this proves that student learning motivation can affect student learning outcomes. with the assumption that the higher the student's learning motivation, the higher the learning outcomes obtained by students.

\section{Interaction between Discovery Learning Model and Learning Motivation on Student Civic Education Learning Outcomes.}

Students who have high learning motivation are taught using conventional learning models will feel less comfortable in learning because they do not have the desire to discuss and exchange ideas, as a result will have difficulty achieving better learning outcomes. If students who have low learning motivation are taught using conventional learning models, they will feel calm because learning information only comes from the teacher.

In line with that Sardiman (2018: 75) states that learning motivation is the overall driving force in students that causes learning activities that ensure the continuity of learning activities and provide direction to learning activities, so that the goals desired by the learning subject can be achieved. Pancasila and Citizenship Education have a good impact on student learning outcomes with the distribution of PPKn learning outcomes of 20 people (100\%) in the above average group. It is also written that self-regulation and social skills both have a positive relationship with Civics learning outcomes and to build the character of students at school, it is necessary to think that parents and teachers at school play an active role with each other. Then when taught with discovery learning,

The results of hypothesis testing using two-way ANOVA for the third hypothesis, namely the interaction between learning models and [538] 
learning motivation in influencing student learning outcomes to get grades $\mathrm{F}_{\text {count }}=2.333$ and a significant value of 0.014 with $\propto=0.05$. then it can be seen that the significant value is $0.014<0.05$. then the hypothesis rejects $\mathrm{Ho}$ and accepts $\mathrm{Ha}$. Which means that there is an interaction between the learning model and motivation to learn in influencing student Civics learning outcomes.

\section{Conclusion}

Based on the formulation, objectives, results and discussion of the research on the influence of discovery learning learning models and learning motivation on learning outcomes of Civics Class IV SDN 105316 Beranti, it can be concluded as follows:

a. There is an effect of student learning outcomes who are taught using discovery learning learning models are higher than students who are taught using conventional learning models who get an average score of 85,919, while learning outcomes using conventional learning models get an average value of 80,000 , the results of the second analysis of variance the learning model shows the calculated $F$ of 4.333 which is greater than the value of $F$ table 3.22 at a significance level of 0.05 so that $\mathrm{HO}$ is rejected. Thus it can be concluded that student learning outcomes using the discovery learning model are higher than the group of students who are taught using conventional learning models.

b. Based on the results of data calculations, it can be seen that the learning outcomes of students who are taught using the discovery learning learning model and have high learning motivation get an average score of 85.07 while students who have low learning motivation get an average of 57.81 . The results of the analysis of 
variance of the two learning models show that the calculated $F$ is 79.45 which is greater than the $F$ table value of 3.22 at a significance level of 0.05 so that $\mathrm{HO}$ is rejected. Thus, it can be concluded that the group of students who have learning motivation obtains higher learning outcomes than the group of students with low learning motivation which is proven to be true.

c. There is an interaction between the learning model and student motivation in influencing learning outcomes. Students with high learning motivation will get higher results if taught with discovery learning learning models and have high learning motivation. Likewise, students who have low learning motivation will get higher learning outcomes if they are taught using the discovery learning model. Based on the results of data calculations, it can be seen that the calculated $\mathrm{F}$ is 8.807 greater than the $F$ table value of 3.22 at a significance level of 0.05 so that $\mathrm{HO}$ is rejected. Thus it can be concluded that there is an interaction between learning models that have high learning motivation on student learning outcomes that are proven to be true.

\section{Bibliography}

Bungana, Reh, dkk. 2018. Pengaruh Strategi Pembelajaran Discovery dan Cara Belajar Siswa Terhadap Karakter Siswa. Jurnal Tematik. Vol. 8, No. 2, Hal. 215-226.

Cand, Anak Agung Bagus Trisna Adi, dkk. 2017. Pengaruh Model Discovery Learning Terhadap Kompetensi Pengetahuan IPA Siswa Kelas VI SD Gugus Yos Sudarso Kecamatan Denpasar Selatan Tahun Pelajaran 2016/2017. Journal PGSD Universitas Pendidikan Ganesha. Vol. 5, No. 2, Hal. 2-10.

Hasnan, Syiti Mutia Hasnan, dkk. 2020. Pengaruh Penggunaan Model Discovery Learning dan Motivasi Terhadap Kemampuan Berpikir 
Kritis Peserta Didik Sekolah Dasar. Jurnal Basicedu. Vol. 4, No. 2, Hal. 239-249.

Kristin, Firosalia, dan Dwi Rahayu. 2016. Pengaruh Penerapan Model Pembelajaran Discovery Learning Terhadap Hasil Belajar IPS Pada Siswa Kelas 4 SD. Scholaria. Vol. 6, No. 1, Hal. 84-92.

Sardiman. 2007. Interaksi dan Motivasi Belajar Mengajar. Jakarta: Raja Grafindo Persada.

Sardiman. 2014. Interaksi dan Motivasi Belajar Mengajar. Jakarta: Rajawali Pers. 